\title{
LRP1B wt Allele
}

National Cancer Institute

\section{Source}

National Cancer Institute. LRP1B wt Allele. NCI Thesaurus. Code C111832.

Human LRP1B wild-type allele is located in the vicinity of 2q21.2 and is approximately $1900 \mathrm{~kb}$ in length. This allele, which encodes low-density lipoprotein receptor-related protein $1 \mathrm{~B}$, is involved in both the metabolism of low density lipoproteins and receptormediated endocytosis. 